\title{
The Problem of German intermediary Translation into Arabic (Goethe's Novel The Sorrows of Young Werther as a model)
}

\author{
Assist. Prof. Dr. Najat Essa Hassen \\ University of Baghdad \\ College of languages \\ German Department
}

\begin{abstract}
There is no doubt that the human beings were blessed by God to have different languages. There are those who speak Semitic languages such as Arabic, Hebrew and Aramaic and there are those who speak Indo-European languages such as Hindi, English, German, etc. This multiplicity normally leads to diversity of the cultures, arts, literatures, and philosophies. Because language is regarded as the means of expressing all these matters, it is necessary to find a way of communication between the different communities. Thus, there has been a need to know and be acquainted with the different languages through the establishment of translation that occurred in the Umayyad and Abbasid eras, especially during the rule of the 5th Umayyad caliph 'Abd al-Malik ibn Marwān, (646-8 October 705). That is because translation was considered a way of the cultural and social communication. Thus, this research is conducted in three parts to discuss the problems of intermediary translation of German literary text into Arabic. The first part talks about the beginning of the Arabic acquaintance with the famous translations of German literary works, especially in Iraq and Egypt to determine the characteristics of this reception. In the second part we will discuss the most famous German novel which translated into Arabic several times and has gained a lot of resonance in the Arab world. It is Die Leiden des jungen Werthers [The Sorrows of young Werther]. Hereby we refer to their translations, in order to see the influence of the intermediary translation on the original text. The third part is talking about the feature of intermediary translation. It must be investigated which problems causes such translation.
\end{abstract}

Keywords: intermediary translation, Goethe, Werther, novel, Azzayaat, German literature

\section{Introduction}

Translation appeared a long time ago as an important means of communication as any language. The dire need to be understood by others led to its' appearance. Signs, gestures as well as repetitions were used to make any sense fully understood. Therefore, Translation comes out as a necessary tool of any human relation to remove language barriers among societies that were similar in nature, but speaking different languages. It was interpreted with the first human gathering worships and multilingualism.

Thus, this research is conducted in three parts to discuss the problems of intermediary translation of German literary text into Arabic. The first part speaks at first briefly about the Arabic acquaintance with the translation in general, and talks in particular about the beginning of the Arabic acquaintance with the famous translations of German literary works, especially in Iraq and Egypt to determine the characteristics of this reception.

In the second part we will discuss the most famous German novel which translated into Arabic several times and has gained a lot of resonance in the Arab world. It is The Sorrows of young Werther [Die Leiden des jungen Werthers] from Johann Wolfgang Goethe, because it was not translated from the source language into Arabic, but from a third language. Hereby we refer shortly to its Arabic translations, in order to see the influence of the intermediate translation on the original text.

The third part sheds light on the term and feature of the intermediary Translation of literary text. It must be investigated which problems causes such translation.

\section{The beginning of the Arabic acquaintance with the translations of German literary works}

Translation has been and still to be an instrument of communication between nations and peoples with different languages. It has emerged as a result of human activities and brought people out of their geographical boundaries to interact with their neighbors. By translation we mean the translation of a term or a text into another language, which enables us to understand the other. This process usually creates an exchange of ideas, which lets everyone know each other's culture. 
In old times, translation played an important role in the dissemination of religious teachings, artistic and literary production, and helped in the interaction among ancient civilizations as Babylonian, Assyrian, Phoenician, Pharaonic and Greek. It was the instrument of understanding between tribes and human gatherings for business activities during peacetime and for conventions that appeared in time of war.

The Arabs have shown great interest in the translation since the beginning of the era of Islam, then especially in the era of the Umayyad state(661-744 AD), where the Umayyad caliph Khalid ibn Yazid ibn Muawiyah (85 AH/ 704) was interested to Arabize the system of government and during the rule of the 5th Umayyad caliph 'Abd al-Malik ibn Marwaan (646-8 October 705). Then the interest in translation was increased in the Abbasid era (750-1258/ 1261$1517 \mathrm{AD})$, because of the conquests that stretched east and west, and required the need to communicate with other nations constantly, and to learn about their cultures, sciences and literature.

Since the $16^{\text {th }}$ century, the number of translations has increased enormously. The reason behind this was that to know the foreign literature better. The majority of what was translated into Arabic after the $16^{\text {th }}$ century AD focused on religious works and books, which was translated from Latin, Greek and Italian. In the era of the Ottoman Albanian commander Muhammad Ali Pasha (4 March 1769 - 2 August 1849), which played a main role with the development of the cultural life in Egypt, reached the translation its peak. He ordered the establishment of Al Alsun School [Languages Institute] 1835 in Egypt, which was headed by Sheikh Refa'ah Al-Tahtawi. During this time, many foreign books were translated and published, especially from French languages ,In this time (1835-1849) nothing was translated directly from German. But through French has created a first model of translation: the indirect translation model."1

The reception of German literary works in the Arab world began in $1900^{2}$, when Niqola Faiadh and Najeb Taraad translated Schiller's drama Kabala und Liebe [Cabal and Love] from French into Arabic. This drama was played at the Russian Consulate in the same year. The same drama was translated by Tanios Abda in 1907 under the title Love and Fraud. Moreover, this drama was translated in 1936 by Hassan Sadiq in Cairo. In addition it was translated by the Egyptian philosopher Abdul Rahman Badawi in 1994. The first three translations of this drama were taken from French, except the last fourth one was taken from German.

A second literary work by Schiller, which was translated in the Arab world, was Die Räuber [The Robbers]. This drama was translated from English into Arabic in 1928 by Abda Hassan Az-Zayat and was played in Syria in 1933. Then it was translated again from English in 1962 by Samir Abdaa. In 1981, another Arabic translation of this drama appeared in Kuwait by Abdul Rahman Badawi.

A third drama by Schiller that appeared in the Arab world was Wilhelm Tell. It was translated from French by Fuad Jabara in Damascus. The Iraqi translator Anwar Shaoul translated this play in 1931, but it was translated into English in 1948 in Cairo by Abaas Abu Shush and Zain Ed-din Faradj. In 1965, Alfons Jacob and Michael Izis also translated this drama into Arabic in Cairo. One suspected that they translated from German, because Jacob was a German teacher. In 1982 an Arabic translation of this play was published in Kuwait by Abdul Rahman Badawi.

Another Schiller's work that was known in the Arab world is Die Jungfrau von Orleans[The Maid of Orleans]. It has been translated into Arabic three times, but unfortunately there is no comment for the source language of these translations. In 1928 it was translated by Shadid Haddad, 1936 by Nazmi Khalil and in 2004 in Kuwait.

Schiller's Maria Stuart was translated in Cairo 1964 from a source language by HilmiMurad, 1967 by Shawqi Mahmoud and 1998 again by HilmiMurad.

In addition, Bertolt Brecht was also translated in the Arab world. Herewith Badawi played a big role. He has translated a lot of Brecht's Plays, like Der kaukasische Kreidekreis[The Chalk Circle]in 1961, Der gute Mensch von Sezuan [The Good Person of Szechwan] in 1965, Die Dreigroschenoper[The Three penny Opera] in 1977, Trommeln in der Nacht [Drums in the Night]in 1977, Mutter Courage und ihre Kinder [Mother Courage and her Children] und Herr Puntila und sein Knecht Matti[Mr. Puntila and his servant Matti] in 1978. He also translated Faust in 1974, Götz von Berlichingen in 1979 and Torquato Tasso in 1980 by Johann Wolfgang Goethe. Because Badawi speaks German, he translated most of these works from German.

Goethe's novel Die Leiden des jungen Werthers has also been translated into Arabic several times from a third language. That is what we will discuss in the next part of this article.

If we look at the Arabic reception of German works and their translations, we realize that it is characterized by:

1. There is several translations of the same work.

\footnotetext{
${ }^{1}$ www.egytrans.org/01/10/13, 09:53. http://www.atida.org/forums/member.php?

${ }^{2}$ https://ar.qantara.de/node/13057.09.06.2005.
} 
2. From the beginning of the twentieth century till the beginnings of the eighties, most works were translated by a third language and not from the original source language.

3. The translators choose works whose themes represent the Arab society and their problems of that time.

Even though translation, being one of the social and cultural means of communication, is considered as important as the language itself. Variations of tongues are the variations of languages.

\section{Goethe's novel [The Sorrows of young Werther] as an example for the Intermediary Translation}

If one looks carefully at Goethe's literary works, which have been translated into Arabic, one realizes that they have not been translated from German into Arabic, but from other language; such as French or English. This part of our research is dedicated to Goethe's novel [The Sorrows of young Werther] and its Arabic translations, especially we concentrate hereby on the translation of the Egyptian translator Ahmed Hassan Azzayaat (1885-1968), because of the acquaintance of this translation in the Arab world. Although this translation contained many mistakes, there is no critic who had contributed to these mistakes. For that reason we will try with this part to find out these mistakes. What prompted us to choose this novel is the first Arabic translation of this novel, which was translated directly from German and published in early 2015 by the Iraqi author living in Berlin NajemWali.

Up to 2015 Goethe's The Sorrows of young Werther was translated into Arabic seven times, but not from German, either from English or from French. The first Arabic translation was published in 1905 by Georg Metraan. The second translation was in 1919 by Ahmed Riyadh. No information was found about the two translators, neither on the Internet nor in the literature. It is worth mentioning, that "A year later, Ahmed Hassan Azzayaat (1885-1968) translated this novel." ${ }^{3}$

In 1927, the same novel was translated by Omer'Abdul Azez Ameen. The fifth Arabic translation was published in 1950 by Nekhla Werd. In 1977, the novel was translated by Nazmi Loqa. The seventh translation was by FuaadFarid, but without a year of publication.

In the Arab world, however; the most widely read translation of this novel is the translation the Egyptian translator Ahmed Hassan Azzayaat, which appeared in 1920 from French. This translation was printed several times in many Arab countries." It was reprinted in 1961. In 1968 it appeared with a foreword by the well-known Egyptian writer Taha Hussein.

Since all these translations were not translated from German, we find, that they contained several errors, such as:

A. The author's name Goethe was changed into Gite by Azzayaat, and into Gaan by NekhlaWerd.

B. The title of the novel was named differently, such as "Ahzaan Goethe [Werther's grief]" by Ahmed Riyadh, or "Werther. Me'saat Gharamiya [Werther. Love tragedy]" by Omer 'Abdul AzezAmeen in 1927.

C. The personal names were translated differently than in German, for example: the name of Goethe's lover "Charlotte", Goethe's friend "Wilhelm", "Albert" and others.

D. In addition, some translations lack some letters of the original text. For example, the letter of August $12^{\text {th }}$ was missed in the translation of FuaadFarid, about seven pages of the original text.

Nevertheless, Azzayaat's Arabic translation remained the most well-known translation of The Sorrows of young Werther, in spite ofthe fact, that it was translated from French. We think, that the renown of this translation was due to the introduction written by the well-known Egyptian writer Taha Hussein. He praised: "Our friend Azzayaat has succeeded in the good selection and the good translation of this novel." ${ }^{5}$

Then, Hussein pointed out the difficulties of changing this novel, when he states: "It is not easy to understand the novel at the first time. On the one hand it is full of emotions, and on the other hand it is full of philosophical views." ${ }^{6}$

When Azzayaat's translation was published in Egypt in 1961 and 1968, it got a special response from the young generation, which was confirmed by Taha Hussein in his introduction: "On behalf of my dear friend, I present this book to the young generation and I am sure that it will attract their attention, and that they will read it carefully and understand it well. We thank the translator for this achievement." ${ }^{7}$

Although Azzayaatspeaks fluent French, we have the following notes on his translation:

1. Some parts of the original text were skipped by Azzayaat, for example he left out some letters, such as the letter of November $22^{\text {th }}$. But one does not know if the French text contains this letter or not.

\footnotetext{
${ }^{3}$ http://shamela.ws/index.php/author/2279. am 02.12.2018. 18:56.

${ }^{4}$ Abboud, Abda (1999): Arabic translations of Goethe. In: Goethe of the genius world. Dar al-Jadid. Voice of Germany. P.94.

${ }^{5}$ Azzayāat (1968): Ahmed Hassan. Die Leiden des jungenWerthers. Al-Qalem publishing house. Beirut. Lebanon. P.16.

${ }^{6}$ Ibid.

${ }^{7}$ Ibid. P.17. 
Sometimes Azzayaat omitted complete sentences, such as the following sentence from the letter of June16 $6^{\text {th }}$ : "I am here again Wilhelm, I want to eat my sandwich for the night and write to you." ${ }^{8}$ This sometimes caused understanding problems with the text. Because the connection between the sentences of the text is missing.

We find another example in the letter of July $1^{\text {st }}$.The translator neglected the name of the village "St ..." ${ }^{9}$, even if it was named by the first two letters by Goethe.

2. In addition, the translator added things which were not in the original text. These additions sometimes made the text strange and incomprehensible, such as:

- In the letter of February $20^{\text {th }} 1772$, the translator added the following Arabic popular cliché: "I wish you joy and children." ${ }^{10}$ However; such a phrase is unfamiliar to a German text, it also made the Arabic text unfamiliar. - In letter of July $20^{\text {th }}$ Azzayaatadded the city "Vienna", in which Goethe had not mentioned any city in the original text: "I should go to *** with the envoy." ${ }^{11}$, but in the Arabic text this sentence was translated as: "I should go to Vienna with the envoy." ${ }^{12}$ With this addition, the translator let the Arab reader think that the storyline plays in Vienna.

- At the end of the letter of May $10^{\text {th }}$, the translator added the following sentence: "And do not confess this to anybody. The others would consider this to be crime. ${ }^{13}$ But in truth there was no secret or other in the original text to confess it.

3. Moreover Azzayaat changed some personal names and wrote them in Arabic as they were pronounced in French. This method has negative results, because it made the names look unfamiliar to the Arab reader, such as the name of a young whom Werther met in the village: "A few days ago I met a young V." ${ }^{14}$ The Egyptian translator changed this name into "Noon": "I met the young Noon a few days ago."15

So it is with the name of Count "C", which the translator changed it into "G", as in: "The count G loves me and respects me."16 The translator also changed the name ofPhilipps into Philipp: "Philipp, you are quite good." ${ }^{17}$ The name "Charlotte" was also changed by Azzayaatinto Charlottin many instances. One of them is: "I found myself on earth among Charlotts children." "Wilhelm" by Goethe: "I ask you, dear Wilhelm." "19 has been called by Azzayaat "William" in different places, such as in "I ask you, dear William."20 Azzayaat translated the name "Schmidt" into "Smith": "The story was not long over when the young pastor came here through the garden with the so-called Herr Smith." ${ }^{21}$ The name "Friederike" by Goethe: "Friederike was very attentive." ${ }^{22}$ was changed into "Friedric": "Friedricwas very attentive." ${ }^{23}$ This name change turned the female name into a male name. "Marianne" in German Textwas translated by Azzayaat into "Mariann", such as in: "Mariann wanted it."24 The name "Albert" was translated into "Alber البير": "Who is Alber? ${ }^{\text {(25 }}$ Also the name Sulzer: "He read all Sulzer's theory, the first part" ${ }^{26}$ was changed into Molzer: "He has completely read Molzer's theory, the first part."27

4. In addition, Azzayaat had translated certain terms differently which changed the actual meaning of the terms, such as:

- "Gifts" in: "Calculate your wealth and what is left of your need, I do not refuse you to make her a gift, just not too often" ${ }^{28}$ has been translated into "antiquities": "Calculate your wealth and what is left of your need, I will not deny you, to give her an antiquity, just not too often. ${ }^{29}$

\footnotetext{
${ }^{8}$ Goethe. Johan Wolfgang (1975): Die Leiden des jungen Werthers. Philipp Reclam Jun. Stuttgart. P.20.

${ }^{9}$ Ibid. P.33.

${ }^{10}$ Azzayaat, Ahmed Hassan(1968): Ibid. P.111.

${ }^{11}$ Goethe. Johan Wolfgang (1975): Ibid. P.45.

${ }^{12}$ Azzayaat, Ahmed Hassan(1968): Ibid. P.71.

${ }^{13}$ Ibid. P.27.

${ }^{14}$ Goethe. Johan Wolfgang (1975): Ibid. P.11.

${ }^{15}$ Azzayaat, Ahmed Hassan(1968): Ibid. P.30.

${ }^{16}$ Ibid. P.112.

${ }^{17}$ Ibid. P.36.

${ }^{18}$ Ibid. P.56.

${ }^{19}$ Goethe. Johan Wolfgang (1975): Ibid. P.48.

${ }^{20}$ Azzayaat, Ahmed Hassan(1968): Ibid. P.76.

${ }^{21}$ Ibid. P.59.

${ }^{22}$ Goethe. Johan Wolfgang (1975): Ibid. P.36.

${ }^{23}$ Azzayaat, Ahmed Hassan(1968): Ibid. P.59.

${ }^{24}$ Azzayaat, Ahmed Hassan(1968): Ibid. P.64.

${ }^{25}$ Ibid. P.49.

${ }^{26}$ Goethe. Johan Wolfgang (1975): Ibid. P.11.

${ }^{27}$ Azzayaat, Ahmed Hassan(1968): Ibid. P.30.

${ }^{28}$ Goethe. Johan Wolfgang (1975): Ibid. P.15.

${ }^{29}$ Azzayaat, Ahmed Hassan(1968): Ibid. P.35.
} 
- "Blond nose": "A little blonde nose." ${ }^{30}$ was translated into "snooty": "A snooty blonde." ${ }^{31}$

- „Excursion“: "I have thought, when I chose with Wahlheim for the purpose of my excursion" ${ }^{32}$ was translated by Azzayaat into "Sport": "I would have thought, when I chose Wahlheim for the purpose of my sport." ${ }^{33}$

- The currency "Taler": "At the moment, I would not have given the boy a thousand talers" ${ }^{34}$ translated Azzayaat into "Dinar": "At that moment, I would not have given the boy a thousand dinars." ${ }^{35}$

- "Knife" in: "Oh, I have taken a knife a hundred times." ${ }^{36}$ was changed by him into "Dagger": "Oh, I have taken a dagger as many times as I have." ${ }^{37}$

- "Paradox": "Paradox! Very paradox!"38 was translated differently: "I have seen something strange."

- The conjunctions "either, or": "Only one thing, my brother, in the world is seldom done with the either-or." ${ }^{40}$ was translated by Azzayaat into "No-Yes": "Only one thing, my brother, in the world is very seldom done with the NoYes." ${ }^{41}$

- "recently" and "maid" in: "Recently I came to the well and found a young maid"42 translated by Azzayaat into: "Yesterday I went to the well and found a girl." 43

- "earlier days" by Goethe in: "And I want to visit him on earlier days" ${ }^{44}$ Azzayaat translated into: "tomorrow morning": "And I want to visit him tomorrow morning." 45

- In the letter of Jun $18^{\text {th }}$ the number of "14" days: "I have to stay here for fourteen days" ${ }^{46}$ was changed by Azzayaat into "15": "I have to stay here for fifteen days."

- The "singer" in the letter of October $12^{\text {th. }}$ "Where is the singer" ${ }^{48}$ was changed by Azzayaat in "poet ":"Where is the poet."

- In the letter of the October $26^{\text {th }}$ changedAzzayaatthe word "feather": "Then I took a feather to write ${ }^{\text {“50 }}$ into "pen":

"Then I took a pen to write.",51

- In the letter of May $15^{\text {th }}$ Azzayaat translated "we" in: "I know well that we are not the same nor can be" ${ }^{52}$ into

"people": "I know well that people are not equal or cannot be. ${ }^{53}$ And so Azzayaat generalized the meaning of the sentence, which is incorrect in the truth.

When we read Azzayaat's translation carefully, we recognize the poetic style of the translator. The standard Arabic language and the poetic style of the translator were able to describe the German phase of "Sturm und Drang [storm and stress]", in which Goethe's novel The Sorrows of Young Werther was written, using a poetic language and lyrical images expressing the feelings of the young generation. But actually the highly lyrical language used by Azzayaat is not understood by all levels of Arab society. That's why we always recommend a simple understandable style of the translator.

\section{The problem of the Intermediary Translation}

${ }^{30}$ Goethe. Johan Wolfgang (1975): Ibid. P.23.

${ }^{31}$ Azzayaat, Ahmed Hassan(1968): Ibid. P.45.

${ }^{32}$ Goethe. Johan Wolfgang (1975): Ibid. P.30.

${ }^{33}$ Azzayaat, Ahmed Hassan(1968): Ibid. P.54.

${ }^{34}$ Goethe. Johan Wolfgang (1975): Ibid. P.44.

${ }^{35}$ Azzayaat, Ahmed Hassan(1968): Ibid. P.70.

${ }^{36}$ Goethe. Johan Wolfgang (1975): Ibid. P.82.

${ }^{37}$ Azzayaat, Ahmed Hassan(1968): Ibid. P.116.

${ }^{38}$ Goethe. Johan Wolfgang (1975): Ibid. P.54.

${ }^{39}$ Azzayaat, Ahmed Hassan(1968): Ibid. P.84.

${ }^{40}$ Goethe. Johan Wolfgang (1975): Ibid. P.48.

${ }^{41}$ Azzayaat, Ahmed Hassan(1968): Ibid. P.76.

${ }^{42}$ Goethe. Johan Wolfgang (1975): Ibid. P.9

${ }^{43}$ Azzayaat, Ahmed Hassan(1968): Ibid. P.28.

${ }^{44}$ Goethe. Johan Wolfgang (1975): Ibid. P.11.

${ }^{45}$ Azzayaat, Ahmed Hassan(1968): Ibid. P.30.

${ }^{46}$ Goethe. Johan Wolfgang (1975): Ibid. P.87.

${ }^{47}$ Azzayaat, Ahmed Hassan(1968): Ibid. P.123.

${ }^{48}$ Goethe. Johan Wolfgang (1975): Ibid. P.97.

${ }^{49}$ Azzayaat, Ahmed Hassan(1968): Ibid. P.133.

${ }^{50}$ Goethe. Johan Wolfgang (1975): Ibid. P.97.

${ }^{51}$ Azzayaat, Ahmed Hassan(1968): Ibid. P.134.

${ }^{52}$ Goethe. Johan Wolfgang (1975): Ibid. P.9.

${ }^{53}$ Azzayaat, Ahmed Hassan(1968): Ibid. P.28. 
The Intermediary Translationmeans a translation of a translation. It may be based on a translated version like a text in German is translated into Arabic via English or French or Spanish. A long list of not only dramatic but also of philosophic subjects has been rendered through this type of translation. "The three works of Nietzsche, for example, have been rendered into Arabic via French not via the original language of the text that is German. These works are: Thus spoke Zarathustra "Also sprach Zarathustra", Philosophy in the Tragic of the Greeks "Die Philosophieimtragischen Zeitalter der Griechen", and On the Genealogy of Morality "ZurGeneologie der Moral". The same could be applied on the works of the philosopher Hegel whose works have been translated via French or English not via the original German text. ${ }^{54,}$

Intermediary Translation is heavily loaded with negative connotations and is often considered as a poor copy of a copy that entails a loss of details, misunderstanding of the meaning or mistranslation as it happened in Al-Zayat's Translation of the German novel The Sorrows of young Werther "Die Leiden des jungen Werthers" via French into Arabic.

One of the other disadvantages of the intermediary translation is the translator's unawareness of the original author's educational background which leads to make a double meaning shift of the original text; the first when the text is rendered into the second language and the second meaning shift is when it is rendered to the Arabic language. Accordingly, the text would lose its high poetic level and turn into a weak prosaic one. This could be applied especially on words with two meanings as in the German word (Schlange) that has two meanings (queue) or (snake). When I was teaching literary text to the second stage of German department at the University of Baghdad, I asked the students to translate the following sentence into Arabic: (Die Leutestehen in langeSchlange), one of the student literally interpreted it as (People are standing in a long snake) and not as (People had long queued). The same mistake could occur when the translator would mistakenly render the meanings according to his own interpretation, making inaccurate meaning shift.

Accordingly, we believe that intermediary translation is incapable of accurately conveying both the idea and the content of the original text, although, it largely depends on the linguistic competence of the Arabic translator as well as on the solidarity of the translated text via which the translation was made into Arabic.

\section{Conclusion and recommendations}

As human community is made of various languages and dialects, Translation appeared as the best means to know those different languages. Living with other societies enable translators to overstep language barriers and open wide means of communication with different cultures, something that enhanced co-living and cooperation among different nations. Thus, Translators played such important roles in all of world great cultural transformation during the long history of civilization. Scholars at European developed countries would not have gained knowledge without learning the language of the culture they are studying. They are but messengers of world peace, without them, the world would have turned into a strange place.

Since Translation is the literary work's passport that can take to another new world, it is important to mention some of the recommendations to enhance and promote it:

1. However, translation remains the first and the last important circle in the chain of cultural dialogue. Neglecting the movement of translation from the foreign language into Arabic means the loss of an opportunity to qualify the Arab community to enter an equal cultural dialogue with the foreign communities. Through translation, the writer or the thinker will be able to overcome the linguistic and cultural barriers to reach the international prospects.

2. Misinterpretation caused by intermediary translation could be avoided by promoting language learning levels through facilitating scholarships, workshops, and periodically held seminars at the country of the foreign language being studied, to enhance language learning from the native speakers and to be in a direct contact with the latest foreign culture development.

3. In addition to the problems of intermediate translation, translation faces other problems and difficulties that include the misconnection with the countries of the foreign languages studied, something that hardens the mutual cultural and education interaction, and blocks the way in the face of getting to know the latest literary and scientific issues.

4. Establishing printing and publishing houses that adopt the process of translation is necessary to overcome such difficulties, and provide translation skills necessary to turn local language scholars into international competent

\footnotetext{
${ }^{54}$ View: Mustafa Zayoor (1983): Twatam and Taboo. Translated by Bo Ali Yassin. Latakia. Cairo. P.2. For more view:

- Reiss (1971): The relation between translation and the nature of the text. In: Möglichkeiten und Grenzen der Übersetzungskritik. München.

-Abd al-Hameed Al-Migrab (1970): Theatrical Issues. Al-Feker library publication. Tripoli. Libya.

-Lamai Al-Maetie (edit) (1992): Seminar on translation and culture development. Cairo: Egyptian General Book Authority.
} 
translators, in addition to making studies, holding seminars and providing the necessary mental and financial support. Mastering over all these obstacles would promote translation and it is then and only then, the process of the "criticism of translation' could be made.

Although there are several methods for translating a text from the source language into the target language, we recommend that translators should respect the original text as much as possible. In addition, the Arabic translator should has a good Arabic style so that all readers of different Arabic societies can understand him.

\section{References}

Abboud.Abda: Arabic translations of Goethe. In: Goethe of the genius world. Dar al-Jadid. Voice of Germany. 1999. Al-Maetie, Lamai (edit): Seminar on translation and culture development. Cairo. Egyptian General Book Authority. 1992.

Al-Migrab, Abd al-Hameed: Theatrical Issues. Al-Feker library publication. Tripoli. Libya. 1970.

Azzayāt: Ahmed Hassan. Die Leiden des jungen Werthers. Al-Qalem publishing house. Beirut. Lebanon. 1968.

Goethe. Johan Wolfgang: Die Leiden des jungen Werthers. Philipp Reclam Jun. Stuttgart. 1975.

Reiss: The relation between translation and the nature of the text. In: Möglichkeiten und Grenzen der Übersetzungskritik. München. 1971.

Zayoor, Mustafa: Twatam and Taboo. Translated by Bo Ali Yassin. Latakia. Cairo. 1983.

http://shamela.ws/index.php/author/2279. am 02.12.2018. 18:56.

www.egytrans.org/01/10/13, 09:53.

http://www.atida.org/forums/member.php?

https://ar.qantara.de/node/13057.09.06.2005. 